\title{
DAMPAK PERGESERAN PERAN DAN FUNGSI KELUARGA PADA PERILAKU MENYIMPANG REMAJA
}

Nunung Sri Rochaniningsih

SMP Negeri 1 Piyungan Bantul

\begin{abstract}
Abstrak
Salah satu masalah sosial yang dikategorikan dalam perilaku menyimpang adalah pergaulan bebas. Pergaulan bebas dikalangan remaja telah mencapai titik yang mengkhawatirkan. Dari hasil penelitian di beberapa kota besar menyatakan bahwa sebagian besar remaja telah melakukan hubungan seks pranikah. Maraknya perilaku menyimpang di kalangan remaja terjadi karena tidak berfungsinya sistem sosial di dalam keluarga dan ketidakharmonisan hubungan anak dengan orang tua. Beberapa peran dan fungsi dalam keluarga telah mengalami pergeseran seiring perkembangan zaman. Hal ini menyebabkan remaja mencari fungsi tersebut di luar lingkungan keluarga. Oleh karena itu perlu diupayakan bagaimana cara untuk membangun kembali peran dan fungsi tersebut dalam keluarga.
\end{abstract}

Kata kunci: perilaku meyimpang, pergaulan bebas, peran dan fungsi keluarga, pergeseran peran dan fungsi keluarga

\section{THE IMPACT OF THE SIFT OF FAMILY ROLE AND FUNCTION ON TEENAGER'S DEVIANT BEHAVIOURS}

\author{
Nunung Sri Rochaniningsih \\ SMP Negeri 1 Piyungan Bantul
}

\begin{abstract}
One of the social problems categorized as a deviant behaviour is promiscuity. Among teenagers, it has reached an alarming point. The results of research in some big cities show that the majority of teenagers have had pre-marital sex. The rise of deviant behavior among teenagers is due to the non-functioning of the social system in the family and the inharmonions relationship between teenagers and their parents. There are shifts in the role and function of family, causing teenagers to look for that function outside their family. Therefore, it is necessary to re-establish the role and the function of the family.
\end{abstract}

Keywords: deviant behaviour, promiscuity, family role and function, shifts 


\section{PENDAHULUAN}

Dewasa ini masyarakat kita merupakan masyarakat modern yang serba kompleks. Kondisi seperti ini merupakan produk dari kemajuan teknologi, mekanisasi, industrialisasi dan urbanisasi, yang telah memunculkan banyak masalah sosial. Masalah-masalah sosial yang dianggap sebagai sosiopatik yang secara sosial kita kenal sebagai penyakit masyarakat atau penyakit sosial (Kartono 1992, pp.3-4).

Pergaulan bebas dalam studi masalah sosial dapat dikategorikan ke dalam perilaku menyimpang. Hal ini terjadi karena terdapat penyimpangan perilaku dari berbagai aturanaturan sosial ataupun dari nilai dan norma sosial yang berlaku. Perilaku menyimpang dapat dianggap sebagai sumber masalah karena dapat mengganggu ketenteraman masyarakat. Tanpa disadari masalah-masalah sosial tersebut ternyata telah melanda kaum remaja kita.

Remaja adalah generasi yang paling berpengaruh dalam mewujudkan cita-cita suatu bangsa, generasi penerus bangsa dan generasi yang diharapkan oleh suatu bangsa untuk merubah keadaan bangsanya menjadi bangsa yang lebih baik. Keadaan remaja Indonesia saat ini sangat memprihatinkan. Hal tersebut dapat dilihat dari kondisi sebagian remaja saat ini yang cenderung lebih bebas dan kurang memperhatikan nilai moral yang terkandung dalam setiap perbuatan yang mereka lakukan.

Remaja putri di kota-kota besar sebagian besar sudah tidak perawan. Pada umumnya mereka telah melakukan hubungan seks pranikah. Hasil penelitian BKKBN menyatakan bahwa sepanjang kurun waktu tahun 2010 separuh remaja putri dikota besar seperti Jabotabek kehilangan keperawanan dan melakukan hubungan seks pranikah. Rentang usia mereka berkisar antara 13-18 tahun. Hal ini tampak pada tabel berikut ini.

Tabel 1. Persentase perempuan lajang yang sudah tidak perawan

\begin{tabular}{clc}
\hline No & \multicolumn{1}{c}{ Kota } & Persentase \\
\hline 1. & Bandung & 47 \\
2. & Medan & 52 \\
3. & Surabaya & 54 \\
\hline
\end{tabular}

Sumber:http://kepri.bkkbn.go.id/Lists/Artikel/ DispForm.aspx? $I D=130 \&$ ContentTypeId $=0 x$ 01003DCABABC04B7084595DA364423DE7 897
Pergaulan bebas di kalangan remaja di beberapa kota besar telah mencapai titik yang mengkhawatirkan. Progran Manajer DKAP PMI Propinsi Riau menyatakan bahwa banyak kasus remaja putri yang hamil karena kecelakaan. Padahal mereka tidak mengerti dan tidak tahu apa resiko yang akan mereka hadapi. Mereka rata-rata berusia 16-23 tahun, datang ke DKAP untuk berkonsultasi karena ia sudah hamil. Mereka yang melakukan konseling ada yang datang sendiri ada juga yang dengan pasangannya. Sebagian besar orang tua mereka tidak tahu (http://tiaraamelia.blogdetik.com/2009/11/03/pergaulan bebas/).

Dari gambaran di atas tampak bahwa saat ini sebagian besar remaja telah kehilangan moralitas. Mereka cenderung berperilaku menyimpang, ada yang memang karena tidak tahu dan ada yang sekedar mengikuti gaya hidup. Penelitian oleh perusahaan riset Internasional Synovate atas nama DKT Indonesia terhadap perilaku seksual remaja berusia 14-24 tahun pernah dilakukan di Medan, Jakarta, Bandung dan Surabaya. Hasil penelitian tersebut mengungkapkan bahwa $64 \%$ remaja mengakui secara sadar melakukan hubungan seks pranikah dan telah melanggar nilai-nilai dan norma agama. Hasil penelitian juga memaparkan bahwa para remaja tersebut tidak memiliki pengetahuan khusus serta komprehensif mengenai seks. Hal ini tampak pada tabel berikut ini

Tabel 2. Sumber informasi remaja tentang seks

\begin{tabular}{clc}
\hline No & \multicolumn{1}{c}{ Sumber } & Persentase \\
\hline 1. & Orang Tua & 5 \\
2. & Sekolah & 19 \\
3. & Film Porno & 35 \\
4. & Teman & 65 \\
\hline
\end{tabular}

Sumber:http://bekompas.blogspot.com/2011/1 O/contoh-makalah-bahayanya-pergaulan.html

Dari tabel di atas dapat dilihat bahwa informasi dari teman lebih dominan dibandingkan orang tua dan guru. Padahal teman sendiri tidak begitu mengerti dengan permasalahan seks ini, karena dia juga mentransformasi dari teman yang lainnya. Hal ini mengidikasikan bahwa remaja kurang terbuka dalam berkomunikasi dengan keluarganya. 
Keluarga telah mengalami perubahan seiring dengan perubahan zaman. Perubahan keluarga tersebut diharapkan mampu mencapai kesejahteraan dan kebahagiaan. Namun, kenyataan sering berbeda dengan harapan. Faktanya peran sosial dan emosional keluarga cenderung bergeser ke peran ekonomis. Menurut Faturohman (2001, p.2) Orang tua yang sibuk bekerja menyebabkan berkurangnya interaksi orang tua dengan anak. Hal ini akan berdampak pada pembentukan kepribadian anak dan remaja menjadi lebih dipengaruhi oleh sekolah dan lingkungan sosialnya, bahkan peran media massa mungkin akan menggantikan peran yang lain. Fenomena ini menunjukkan bahwa telah terjadi pergeseran peran dan fungsi keluarga dalam hal sosialisasi. Keluarga kurang memiliki fungsi sosialisasi, yang diharapkan untuk menanamkan nilai-nilai dan norma-norma pada anakanaknya.

Kurangnya perhatian orang tua, kurangnya penanaman nilai-nilai agama berdampak pada pergaulan bebas dan berakibat remaja dengan gampang melakukan hubungan suami istri di luar nikah sehingga terjadi kehamilan. Pada kondisi ketidaksiapan berumah tangga dan untuk menghindari tanggung jawab, maka terjadilah aborsi.

Oleh karena itu perlu dicari solusi untuk dapat meminimalisasi pergaulan bebas di kalangan remaja. Bagaimana peran dan fungsi keluarga mampu mengatasi pergaulan bebas di kalangan remaja.

\section{PEMBAHASAN}

\section{Perilaku Menyimpang}

Istilah penyimpangan atau deviance telah lama ada dalam sosiologi. Makna istilah penyimpangan lebih ditekankan pada makno konotatifnya. Perilaku menyimpang atau social deviance merupakan bentuk perilaku yang tidak sesuai dengan norma-norma sosial yang ada. Rock dalam Dadang Supardan (2011, p.144) mengartikan perilaku menyimpang sebagai perilaku yang terlarang, perlu dibatasi, disensor, diancam hukuman, atau label lain yang dianggap buruk. Pengertian perilaku menyimpang tersebut lebih disepadankan dengan pelanggaran aturan. Namun, sebenarnya istilah penyimpangan memiliki makna lebih luas daripada kriminalitas, karena sebenarnya yang melakukan penyimpangan tersebut tidak sepenuhnya melanggar secara kriminal.

Istilah penyimpangan terkadang memiliki makna yang kurang jelas. Namun, istilah penyimpangan lebih mengarah pada perilaku yang dianggap aneh yang dapat memenuhi kebutuhan untuk memuaskan rasa ingin tahu. Beberapa sosiolog memiliki pen-dapat yang bergam tentang perilaku menyim-pang. Matza dalam Dadang Supardan (2011, p.145) mengaitkan penyimpangan dengan evaluasi majemuk, pergeseran standar penilaian, dan ambivalensi moral. Garfinkel dalam Dadang Supardan (2011, p.145) menyatakan bahwa penyimpangan sebagai cerminan upaya penyesuaian diri sebagian anggota masyarakat dalam mengatasi persoalannya, yang tidak jarang berbenturan dengan standar umum. Menurut Kartono (1992, p.21 ) delinkuen merupakan produk konstitusi mental serta emosi yang sangat labil dan defektif sebagai akibat dari proses pengkondisian lingkungan buruk terhadap seseorang. Pendapat lain dikemukakan oleh Scott dan Douglas dalam Dadang Supardan (2011, p.145) yang menyatakan bahwa yang terpenting dari ciri penyimpangan adalah adanya penilaian dari pihak lain yang menganggapnya memiliki perilaku aneh.

Dengan demikian yang dimaksud dengan perilaku menyimpang adalah suatu tindakan yang tidak sesuai atau tidak dapat menyesuaikan diri dengan norma-norma yang berlaku di masyarakat. Tindakan perilaku menyimpang tersebut dilakukan baik secara sadar ataupun tidak sadar.

Perilaku menyimpang apabila terus berkembang akan menyebabkan timbulnya penyakit sosial dalam masyarakat. Adapun bentuk-bentuk penyimpangan yang ada dalam masyarakat antara lain: (1) minuman keras; (2) menyalahgunaan narkotika; (3) perkelahian antarpelajar; (4) perilaku seks di luar nikah; (5) berjudi; dan (6) tindak kejahatan (kriminalitas).

Hal yang lebih rinci dikemukakan oleh Kartini Kartono (1992, p.21) bahwa wujud dari perilaku delikuen antara lain:

1) Kebut-kebutan di jalanan yang akibatnya mengganggu keamanan lalu lintas. Disamping itu juga membehayakan diri sendiri dan orang lain.

2) Perilaku ugal-ugalan, berandalan, urakan yang mengacaukan ketentraman masyarakat sekitar. 
3) Perkelahian antar geng, antar kelompok, antar sekolah, antar suku sehingga kadang-kadang membawa korban jiwa.

4) Membolos sekolah lalu menggelandang sepanjang jalan, atau bersembunyi di tempat-tempat terpencil sambil melakukan eksperimen bermacam-macam tindakan kriminal.

5) Kriminalitas anak, remaja, adolesens antara lain berupa perbuatan mengancam, intimidasi, memeras, mencuri, mencopet, merampas, menjambret, menyerang, merampok, membunuh, tindak kekerasan dan pelanggaran lainnya.

6) Berpesta pora sambil mabuk-mabukan, melakukan hubungan seks bebas, atau orgi (mabuk-mabukan hebat dan menimbulkan keadaan yang kacau balau yang mengganggu lingkungan).

7) Perkosaan, agresivitas seksual dan pembunuhan dengan motif seksual, atau didorong oleh reaksi-reaksi kompensatoris dari perasaan inferior, menuntut pengakuan diri, depresi hebat, rasa kesunyian, emosi balas dendam, kekecewaan ditolak cintanya.

8) Kecanduan dan ketagihan bahan narkotika yang akhirnya erat kaitannya dengan tindak kejahatan.

9) Tindakan-tindakan amoral seksual secara terang-terangan tanpa tedeng aling-aling, tanpa rasa malu dengan cara yang kasar.

10) Homoseksualitas, erotisme anal dan oral, dan gangguan seksual lainnya.

11) Perjudian dan bentuk-bentuk permainan lain dengan taruhan, sehingga mengakibatkan dampak kriminal.

12) Komersialisasi seks, pengguguran janin oleh gadis-gadis delikuen dan pembunuhan bayi oleh ibu-ibu yang tidak kawin.

13) Tindakan radikal dan ekstrim, dengan cara kekerasan, penculikan dan pembunuhan yang dilakukan oleh anak-anak remaja.

14) Perbuatan asosial dan anti sosial lainnya yang disebabkan oleh gangguan kejiwaan pada anak-anak dan remaja psikopatik, psikotik, neurotik dan menderita gangguan-gangguan jiwa lainnya.

15) Tindak kejahatan disebabkan oleh penyakit tidur, dan ledakan meningitis serta post encephalitics juga luka di kepala dengan kerusakan pada otak ada kalanya menyebabkan kerusakan mental sehingga orang yang bersangkutan tidak mapu melakukan kontrol diri.

16) Penyimpangan tingkah laku disebabkan oleh kerusakan pada karakter anak yang menuntut kompensasi yang disebakan adanya organ-organ yang inferior.

Beberapa penyebab terjadinya penyimpangan seorang individu antara lain :

1) Ketidaksanggupan menyerap norma-norma kebudayaan.

Seseorang yang tidak sanggup menyerap norma-norma kebudayaan ke dalam kepribadiannya, ia tidak dapat membedakan hal yang pantas dan tidak pantas. Keadaan itu terjadi akibat dari proses sosialisasi yang tidak sempurna, misalnya karena seseorang tumbuh dalam keluarga yang retak (broken home). Apabila kedua orang tuanya tidak bisa mendidik anaknya dengan sempurna maka anak itu tidak akan mengetahui hak dan kewajibannya sebagai anggota keluarga.

2) Proses belajar yang menyimpang.

Seseorang yang melakukan tindakan menyimpang karena seringnya membaca atau melihat tayangan tentang perilaku menyimpang. Hal itu merupakan bentuk perilaku menyimpang yang disebabkan karena proses belajar yang menyimpang. Karier penjahat kelas kakap yang diawali dari kejahatan kecil-kecilan yang terus meningkat dan makin berani/nekad merupakan bentuk proses belajar menyimpang.

3) Ketegangan antara kebudayaan dan struktur sosial.

Terjadinya ketegangan antara kebudayaan dan struktur sosial dapat mengakibatkan perilaku yang menyimpang. Hal itu terjadi jika dalam upaya mencapai suatu tujuan seseorang tidak memperoleh peluang, sehingga ia mengupayakan peluang itu sendiri, maka terjadilah perilaku menyimpang.

4) Ikatan sosial yang berlainan.

Setiap orang umumnya berhubungan dengan beberapa kelompok. Jika pergaulan itu mempunyai pola-pola perilaku yang menyimpang, maka kemungkinan ia juga akan mencontoh pola-pola perilaku menyimpang.

5) Akibat proses sosialisasi nilai-nilai subkebudayaan yang menyimpang. Seringnya media massa menampilkan berita 
atau tayangan tentang tindak kejahatan (perilaku menyimpang). Hal inilah yang dikatakan sebagai proses belajar dari subkebudayaan yang menyimpang.

\section{Pergaulan Bebas sebagai Perilaku Menyimpang pada Remaja}

Pergaulan bebas adalah salah satu bentuk dari perilaku menyimpang yang saat ini marak terjadi di kalangan remaja. Adapun kata "bebas" yang dimaksud adalah melewati batas-batas norma yang ada. Masalah pergaulan bebas yang sering kali kita dengar meliputi perilaku yang tidak terkendali, seperti sex bebas dan penggunaan narkoba yang berujung kepada penyakit seperti HIV dan AIDS ataupun kematian. Dalam pembahasan kali ini yang dimaksud pergaulan bebas lebih menekankan pada perilaku sex bebas di kalangan Remaja. Remaja adalah individu labil yang emosinya rentan tidak terkontrol oleh pengendalian diri yang benar. Masalah keluarga, kekecewaan, pengetahuan yang minim, dan ajakan teman-teman yang bergaul bebas membuat makin berkurangnya potensi generasi muda Indonesia dalam kemajuan bangsa.

Remaja adalah masa peralihan dari kanak-kanak ke dewasa. Para ahli pendidikan sependapat bahwa remaja adalah mereka yang berusia antara 13 sampai dengan 18 tahun. Menurut Siti Irine ( 2012: 69 ) bahwa umur antara 12 sampai 18 tahun berada pada fase perkembangan Ego-identity vs Role on fusion. Pada tahap ini manusia ingin mencari identitas dirinya. Anak yang sudah beranjak menjadi remaja mulai ingin tampil memegang peranperan sosial di masyarakat. Namun masih belum bisa mengatur dan memisahkan tugas dalam peran yang berbeda.

Seorang remaja sudah tidak lagi dapat dikatakan sebagai kanak-kanak, namun masih belum cukup matang untuk dapat dikatakan dewasa. Taraf perkembangan dan pertumbuhan telah menjadikan perubahan pada diri remaja. Perubahan perilaku tidak akan menjadi masalah bagi orang tua apabila anak tidak menunjukkan tanda penyimpangan.

Mereka sedang mencari pola hidup yang paling sesuai baginya dan inipun sering dilakukan melalui metode coba-coba walaupun melalui banyak kesalahan. Kesalahan yang dilakukan sering menimbulkan kekhawatiran serta perasaan yang tidak menye- nangkan bagi lingkungan dan orang tuanya. Hal ini cukup beralasan karena anak remaja kemungkinan akan berbuat apa saja tanpa memikirkan resiko yang akan ditanggungnya.

Perilaku menyimpang pada anak remaja terjadi karena tidak berfungsinya sistem sosial di lingkungan masyarakat dan ketidak harmonisan hubungan anak dengan orang tua. Hubungan orang tua dan anak sangat dipengaruhi oleh persepsi anak terhadap sistem pengasuhan dan interpretasinya terhadap motivasi dan hukuman dari orang tua. Hal ini sesuai dengan pendapat Hurlock (dalam Silalahi, 2010: 103) bahwa interaksi dalam keluarga akan berlangsung tidak wajar jika sikap orang tua dipersepsikan tidak baik oleh anak. Oleh karena itu keluarga memiliki fungsi dan peran yang penting dalam pengasuhan dan pembinaan terhadap perilaku anak.

\section{Peran dan Fungsi Keluarga}

Keluarga sebagai unit terkecil dalam kehidupan sosial sangat besar perananya dalam membentuk pertahanan seseorang terhadap serangan penyakit sosial sejak dini. Orang tua yang sibuk dengan kegiatannya sendiri tanpa mempedulikan bagaimana perkembangan anak-anaknya merupakan awal dari rapuhnya pertahanan anak terhadap serangan penyakit sosial. Sering kali orang tua hanya cenderung memikirkan kebutuhan lahiriah anaknya dengan bekerja keras tanpa mempedulikan bagaimana anak-anaknya tumbuh dan berkembang.

Namun peran orang tua dalam pengasuhan anak berubah seiring pertumbuhan dan perkembangan anak. Ayah dan ibu sama-sama memiliki peran yang penting sejak anak dalam kandungan. Namun ada sedikit perbedaan sentuhan dari apa yang ditampilkan oleh ayah dan ibu (Roslina dalam Silalahi, 2010, p.180). Ibu cenderung menumbuhkan perasaan mencintai dan mengasihi anak melalui interaksi yang melibatkan sentuhan fisik dan kasih sayang. Sedangkan ayah cenderung menumbuhkan rasa percaya diri dan kompeten pada anak melalui kegiatan bermain yang melibatkan fisik. Orang tua memiliki peran penting dalam pengasuhan dan pembinaan terhadap perilaku anaknya. Dalam perkembangan anak orang tua berperan sebagai pemuas kebutuhan anak, tumbuh kembang anak, teladan bagi anak, dan pembentuk konsep diri dalam keluarga. 
Keluarga terdiri dari pribadi-pribadi yang merupakan bagian dari jaringan sosial yang lebih besar. Oleh karena itu tugas-tugas keluarga merupakan tanggung jawab langsung setiap pribadi dalam masyarakat. Ciri utama dari sebuah keluarga adalah bahwa fungsi utama dari keluarga dapat dipisahkan satu sama lain (Goode, 2007, p.9). Fungsi tersebut antara lain: (1) kelahiran; (2) pemeliharaan fisik anggota keluarga; (3) penempatan anak dalam masyarakat; (4) kontrol sosial.

Pendapat senada tentang fungsi keluarga dikemukakan oleh Munandar (Dwiningrum, 2012, p.109) antara lain: (1) pengaturan seksual; (2) reproduksi; (3) sosialisasi; (4) pemeliharaan; (5) penempatan anak di dalam masyarakat; (6) pemuas kebutuhan seseorang; dan (7) kontrol sosial.

Dengan fungsi sosial keluarga mempunyai peran yang sangat penting dalam pembentukan individu yang bermoral.

Keterlibatan keluarga secara aktif dalam pengasuhan anak dilaksanakan melalui fungsi keluarga. Menurut Silalahi (2010, p.184) ada delapan fungsi keluarga, yaitu:

1) Fungsi Keagamaan dengan memberikan contoh ritual keagamaan yang dianut keluarga kepada anak.

2) Fungsi sosial budaya melalui kebiasaan membacakan cerita atau legenda, mengenalkan musik, seni dan tarian daerah.

3) Fungsi cinta kasih, dengan memberikan contoh cara berinteraksi dengan orang lain.

4) Fungsi perlindungan, dengan memberikan contoh hidup sehat, mendorong agar anak mau menceritakan apa yang dirasakan.

5) Fungsi reproduksi, dengan menerangkan pentingnya kebersihan diri terutama setelah dari kamar kecil.

6) Fungsi sosialisasi dan pendidikan, dilakukan dengan mengajarkan kebiasaan berinteraksi yang baik.

7) Fungsi ekonomi, melalui pembinaan perilaku anak dalam aspek ekonomi seperti kebiasaan menabung, hidup hemat, mengatur uang yang dimiliki dan sebagainya.

8) Fungsi pemeliharaan lingkungan, dengan memberikan contoh cara membersihkan rumah, merawat tanaman, dan memelihara hewan piaraan.
Pendapat lain tentang fungsi dari keluarga menurut kajian Haviland (dalam Silalahi, 2010, p.6) adalah masalah seksual dan pemeliharaan anak. Dalam hal masalah seksual dikenal pengendalian yang berbentuk pernikahan. Sedangkan dalam hal pemeliharaan anak jika dilihat dari konteks sederhana hanya berkisar pada pemeliharaan fisik seperti memberi makan, menjaganya dari gangguan luar yang berupa fisik dan sebagainya.

Dari empat pendapat tersebut ada beberapa hal persamaan tentang fungsi keluarga, salah satunya adalah fungsi pemeliharaan anak. Dalam hal ini fungsi pemeliharaan anak tidak boleh dilihat hanya dari pemeliharaan fisik. Sebenarnya ada fungsi lain yang tersirat dalam fungsi tersebut yaitu membentuk karakter dan perilaku anak untuk bisa hidup di kalangan masyarakat. Selain itu pemeliharaan anak juga mengandung proses sosialisasi yang secara khusus ditekankan oleh ibu mulai dari dalam kandungan.

Pada kenyataannya ada beberapa kasus di keluarga dimana peran dan fungsi keluarga tidak berjalan sebagaimana mestinya. Sementara itu kita tahu betapa pentingnya keluarga terutama bagi perkembangan kepribadian seseorang. Gangguan pada pertumbuhan kepribadian seseorang mungkin disebabkan pecahnya kehidupan keluarga secara fisik maupun mental. Sehingga fungsi dan peran keluarga mengalami kegagalan

Menurut Silalahi (2010, p.186) kegagalan-kegagalan dalam menjalankan fungsi keluarga dapat disebabkan karena beberapa faktor. Adapun faktor-faktor tersebut antara lain:

1) Faktor pribadi. Dimana suami-istri kurang menyadari akan arti dan fungsi perkawinan yang sebenarnya. Misalnya, sifat egoisme, kurang adanya toleransi, kurang adanya kepercayaan satu sama lain.

2) Faktor situasi khusus dalam keluarga, beberapa diantaranya adalah :

a) Kehadiran terus menerus dari salah satu orang tua baik dari pihak suami ataupun istri.

b) Karena istri bekerja dan mendanbakan kedudukan yang lebih tinggi dari suaminya.

c) Tinggal bersama keluarga lain dalam satu rumah. 
d) Suami-istri sering meninggalkan rumah karena kesibukan di luar.

Pendapat lain disampaikan oleh Kartini Kartono (1992, p.65) bahwa beberapa kasus remaja yang delinkuen disebabkan terganggunya fungsi ibu sebagai pendidik dan pelindung dalam keluarga. Adapun bentuk perilaku ibu tersebut antara lain:

a) Hubungan antara ibu dengan anak yang tidak harmonis.

b) Perpisahan dengan ibu kandung pada tahun-tahun awal usia anak.

c) Menjauhkan anak dari rasa aman terlindung

d) Terputusnya hubungan simbiotik antara ibu dengan anak

\section{Sosialisasi dalam Keluarga}

Pengertian sosialisasi lebih ditekankan pada sesuatu hal yang khusus sengaja diajarkan dan diberikan kepada seorang anggota baru. Dengan adanya sosialisasi tersebut akan terbentuk ketrampilan-ketrampilan dan karakteristik yang bisa mengembangkan individuindividu baru (Georgas dalam Silalahi, 2010, p.7).

Pengertian lain tentang sosialisasi adalah proses yang harus dilalui manusia muda untuk memperoleh nilai-nilai dan pengetahuan mengenai kelompoknya dan belajar mengenai peran sosialnya (Goode, 2007, p.20). Karena manusia lebih tergantung pada proses belajar dan tidak dapat berkembang secara wajar tanpa kontak sosial.

Dari pengertian para ahli tentang sosialisasi diatas dapat kita simpulkan bahwa sosialisasi merupakan proses yang harus dilalui oleh setiap manusia dalam kehidupannya. Dengan sosialisai inilah akan diperoleh nilai-nilai dan pengetahuan. Sosialisasi juga berfungsi membentuk ketrampilan dan karakteristik pada anak-anak.

Sosialisasi merupakan proses sangat penting yang harus dilalui oleh setiap manusia. Dalam kehidupan manusia sosialisasi memiliki berbagai tujuan penting baik bagi individu, keluarga maupun masyarakat. Menurut Leonard Broon (Dwiningrum, 2012, p.70) sosialisasi memiliki tujuan sebagai berikut:

1) Disiplin

Dalam sosialisasi diajarkan tentang dasar-dasar disiplin dari yang sederhana sampai pada metode ilmu pengetahuan. Masih segar dalam ingatan kita, sejak anak-anak kita sudah dilatih untuk disiplin. Misalnya dengan adanya aturan-aturan mandi dua kali sehari, harus tidur siang, harus mencuci tangan sebelum makan dan sebagainya. Disamping itu penerapan disiplin tidak hanya pada aktivitas di rumah saja, tetapi juga menyangkut kegiatankegiatan di luar rumah. Misalnya disiplin dalam berlalu lintas, dalam bekerja, dalam belajar dan sebagainya.

2) Aspirasi

Sebagaimana tentang kedisiplinan, sosialisasi juga mengajarkan tentang aspirasi-aspirasi. Aspirasi dalam suatu masyarakat mungkin tidak sama, tetapi masyarakat mempunyai aspirasi tertentu yang nantinya juga berpengaruh pada anggota masyarakatnya. Contoh pada lingkungan masyarakat petani maka akan banyak orang tua yang menginginkan anaknya menjadi petani juga. Pada umumnya aspirasi dapat dikaitkan dengan tujuan dari masing-masing individu.

3) Identitas

Sosialisasi memberikan identitas kepada individu melalui aspirasi-aspirasinya. Dengan sosialisasi individu belajar untuk mencari konsep dirinya atau identitas dirinya. Contoh seorang anak perempuan akan berusaha bagaimana menjadi seorang anak perempuan yang baik, yang tentu saja akan berbeda bila dia menjadi anak laki-laki.

4) Peran

Di dalam sosialisasi diajarkan tentang hak dan kewajiban yang harus dilakukan dengan status yang dimilikinya. Sebagai contoh kalau kita menanyakan tentang identitas kita dengan pertanyaan "siapa saya?" maka selain identitas kita yang terjawab, juga termasuk menjawab pertanyaan peran apa yang harus dimainkan.

Proses sosialisasi yang pertama dan utama terjadi dalam lingkungan keluarga. Dimana di lingkungan keluarga terjadi interaksi dan disiplin pertama dalam kehidupan sosial untuk membentuk suatu kepribadian. Orang tua berperan sebagai pendidik pertama bagi anak-anaknya. Orang tua menanamkan nilai-nilai hidup dalam keluarga. Namun 
demikian dengan pergeseran fungsi dan peran keluarga menyebabkan terjadinya penurunan fungsi dan peran keluarga dalam penanaman nilai-nilai hidup. Perubahan peran keluarga yang relatif cepat akan memberikan kontribusi pada adanya ketegangan dalam keluarga. (Silalahi, 2010, p.10)

Pada kondisi seperti ini keluarga bukan lagi menjadi tempat untuk bercerita dan berbagi pengalaman bagi anak. Anak akan mencari tempat yang mampu dan mau menampung semua kegelisahannya. Anak akan mencari tempat berlindung di lingkungan masyarakat atau di lingkungan teman sebayanya. Dengan demikian anak akan mencari afeksi di luar lingkungan keluarga.

Teman sebaya merupakan hal yang penting dan merupakan sumber untuk memperoleh afeksi, simpati dan tuntunan moral. Dari hasil penelitian skynovate research dinyatakan pengetahuan tentang sex remaja $65 \%$ diperoleh dari teman sebayanya. Walaupun sebenarnya informasi yang diberikan oleh teman sebaya belum tentu benar, akan tetapi mereka berusaha untuk mengikuti perilakunya agar dapat disukai dan diterima oleh kelompoknya. Hal ini menunjukkan telah terjadinya proses sosialisasi yang kurang sempurna pada diri anak remaja.

\section{Bergesernya Peran dan Fungsi Keluarga}

Munculnya kenakalan remaja merupakan gejolak kehidupan yang disebabkan adanya perubahan sosial di masyarakat. Perubahan tersebut misalnya pergeseran fungsi dan peran keluarga.

Peran dan fungsi keluarga telah mengalami pergeseran pada masyarakat modern. Peran dan fungsi keluarga sebagai lembaga sosialisasi dan afeksi telah mengalami perubahan. Hal ini menyebabkan terganggunya proses sosialisasi anak dalam keluarga. Oleh karena itu saat ini banyak anak remaja yang berperilaku menyimpang, dan sebagian besar penelitian mengindikasikan telah terjadi pergaulan bebas (sex bebas) di kalangan remaja.

Anggapan umum bahwa teknologi dan industrialisasi merupakan faktor utama terjadinya pergeseran peran dan fungsi keluarga. Menurut William F Ogburn (dalam Goode, 2007, p.215) bahwa penggerak utama perubahan sosial adalah teknologi. Dalam teorinya tentang perubahan keluarga Ogburn memandang bahwa keluarga modern telah kehilangan fungsinya karena adanya industrialisasi. Industrialisme modern telah memberikan wanita lebih banyak kebebasan ekonomi, tetapi tidak melepaskan mereka dari tugastugas rumah tangga.

Seorang ibu yang bekerja cenderung merasakan adanya ikatan yang kuat terhadap anak-anaknya sehingga berusaha menghindari membebani mereka dengan pekerjaan rumah tangga. Selain itu juga berusaha mengalihkan kompensasi rasa mentelantarkan anak-anaknya dengan melindungi mereka dan memecahkan kesulitan yang mereka hadapi (Goode, 2007, p.156). Hal ini menyebabkan anak menjadi bermanja-manja dan menujukkan kemampuan yang lebih rendah. Sehingga mereka akan kesulitan bila menghadapi persoalan yang rumit. Anak-anak tersebut cenderung tidak dapat menyesuaikan diri sehingga menghadapinya dengan cara-cara mengalihkan permasalahan ke hal-hal yang kurang baik.

Secara umum telah terjadi pergeseran peran dan fungsi keluarga dalam sebagian masyarakat Indonesia. Dari beberapa kasus yang orang tuanya bekerja semua, ditemukan ada beberapa peran dan fungsi keluarga yang telah mengalami pergeseran. Peran dan fungsi keluarga tersebut antara lain:

\section{Fungsi Sosialisasi.}

Fungsi sosialisasi ini berperan untuk mendidik anak mulai dari awal sampai pertumbuhan anak sehingga terbentuk kepribadian. Anak-anak harus mendapat sosialisasi oleh orang tuanya tentang nilai-nilai apa yang dibolehkan dan tidak boleh, apa yang baik dan tidak baik, apa yang pantas dan tidak pantas dan sebagainya. Karena kesibukan orang tua terkadang mereka lalai dalam memberikan sosialisasi kepada anaknya. Bahkan mereka cenderung menyerahkan pada lembaga yang lain seperti sekolah. Sementara anak hanya dalam waktu terbatas berada di sekolah, selebihnya mereka cenderung mencari dari lingkungannya bahkan dari media massa.

\section{Fungsi Perlindungan}

Fungsi perlindungan dalam arti bahwa keluarga berfungsi untuk melindungi seluruh anggota keluarga dari berbagai bahaya yang dapat mengancam kelangsungan hidup dan keberadaan suatu keluarga. Seluruh anggota keluarga hendaknya bekerjasama untuk saling 
melindungi satu sama lain yang pada akhirnya dapat menimbulkan rasa nyaman dan tentram di dalam diri masing-masing anggota keluarga tersebut.

\section{Fungsi Afeksi}

Fungsi afeksi dalam arti bahwa keluarga berkewajiban untuk memberikan rasa kasih sayang kepada tiap-tiap anggota keluarga yang ada di dalamnya, agar mereka dapat merasakan hidup sebagai mana mestinya. Salah satu kebutuhan dasar manusia adalah kebutuhan kasih sayang atau rasa dicintai. Dalam keluarga yang harmonis akan terjadi komunikasi yang dialogis antara anggota keluarganya. Sehingga masing-masing anggota berkesempatan untuk sekedar berkeluh kesah tentang apa yang dirasakan, tentang apa yang dilakukan dalam sehari. Sehingga masingmasing anggota keluarga merasa diperhatikan, dihargai dan dicintai. Apabila tidak ada komunikasi dalam keluarga atau terjadi budaya bisu dalam keluarga maka anak cenderung akan mencari fungsi afeksi di luar keluarganya.

\section{Fungsi Rekreasi}

Karena berkurangnya kuantitas dan kualitas pertemuan dalam keluarga, maka keluarga bukan lagi menjadi tempat rekreasi bagi anggotanya. Dimana keluarga menjadi tempat bertemu, bercengkrama, berbagi pekerjaan, masalah maupun afeksi untuk meringankan beban fisik dan psikologis.

Bergesernya keempat fungsi keluarga di atas merupakan faktor dominan terjadinya kenakalan remaja, walaupun sebenarnya ada banyak sebab remaja melakukan pergaulan bebas. Penyebab tiap remaja mungkin berbeda tetapi semuanya berakar dari penyebab utama yaitu kurangnya pegangan hidup remaja dalam hal keyakinan atau agama dan ketidakstabilan emosi remaja. Berikut ini antara lain penyebab maraknya pergaulan bebas di Indonesia:

1. Sikap mental yang tidak sehat

Sikap mental yang tidak sehat membuat banyaknya remaja merasa bangga terhadap pergaulan yang sebenarnya merupakan pergaulan yang tidak sepantasnya, tetapi mereka tidak memahami karena daya pemahaman yang lemah. Dimana ketidakstabilan emosi yang dipacu dengan penganiayaan emosi seperti pembentukan kepribadian yang tidak sewajarnya dikarenakan tindakan keluarga ataupun orang tua yang menolak, acuh tak acuh, menghukum, mengolok-olok, memaksakan kehendak, dan mengajarkan yang salah tanpa dibekali dasar keimanan yang kuat bagi anak, yang nantinya akan membuat mereka merasa tidak nyaman dengan hidup yang mereka biasa jalani. Sehingga pelarian dari hal tersebut adalah hal berdampak negatif, contohnya dengan adanya pergaulan bebas.

2. Pelampiasan rasa kecewa

Yaitu ketika seorang remaja mengalami tekanan dikarenakan kekecewaannya terhadap orang tua yang bersifat otoriter ataupun terlalu membebaskan, sekolah yang memberikan tekanan terus menerus(baik dari segi prestasi untuk remaja yang sering gagal maupun dikarenakan peraturan yang terlalu mengikat), lingkungan masyarakat yang memberikan masalah dalam sosialisasi. Sehingga menjadikan remaja sangat labil dalam mengatur emosi, dan mudah terpengaruh oleh hal-hal negatif di sekelilingnya, terutama pergaulan bebas dikarenakan rasa tidak nyaman dalam lingkungan hidupnya.

3. Kegagalan remaja menyerap norma

Hal ini disebabkan karena normanorma yang ada sudah tergeser oleh modernisasi.

\section{Upaya Penanggulangan Pergaulan Bebas Menurut Perspektif Teori Struktural- Fungsional}

Dalam hal ini penulis akan menganalisis permasalahan tentang pergaulan bebas akibat dari pergeseran peran dan fungsi keluarga dari perspektif teori struktural fungsional. Teori ini menekankan pada keteraturan dan mengabaikan konflik dan perubahanperubahan sosial yang ada di masyarakat.

Teori struktural fungsional adalah salah satu teori sosiologi yang memandang bahwa masyarakat sebagai suatu sistem yang saling terkait satu dengan yang lain. Masyarakat sebagai suatu sistem memiliki struktur yang terdiri dari banyak lembaga, dan masingmasing lembaga memiliki fungsi sendirisendiri. Misalnya lembaga keluarga berfungsi mewariskan nilai-nilai yang ada kepada anggota keluarganya yang baru (Zamroni, 1992, pp.25-26). 
Struktural fungsional menekankan pada keseimbangan sistem yang stabil dalam keluarga agar dapat berfungsi dengan baik dan kestabilan sosial dalam masyarakat. Oleh karena itu pendekatan ini tidak pernah lepas dari pengaruh nilai-nilai, norma dan budaya yang melandasi sistem masyarakat tersebut.

Menurut Ritzer (2003, p.21) bahwa masyarakat merupakan suatu sistem sosial yang terdiri dari bagian-bagian atau elemen yang saling berkaitan dan saling menyatu dalam keseimbangan. Teori ini beranggapan bahwa perubahan yang terjadi pada bagian, akan membawa perubahan pula terhadap bagian lain. Asumsi dasarnya adalah bahwa setiap struktur dalam sistem sosial, fungsional terhadap yang lain.

Menurut Spencer (dalam Poloma, 2007, p.24) bahwa masyarakat sebagai suatu organisasi hidup yang memiliki ciri-ciri sebagai berikut:

a. Masyarakat dan organism hidup samasama mengalami pertumbuhan bersamasama berubah dan tumbuh.

b. Karena disebabakan oleh pertumbuhan dalan ukurannya maka struktur sosial maupun organisme mengalami pertumbuhan pula.

c. Tiap bagian yang tumbuh dari organism biologis maupun organisme sosial memiliki fungsi dan tujuana tertentu dan tumbuh menjadi organism yang berbeda dengan tugas masing-masing yang berbeda pula.

d. Perubahan yang ada dalam suatu bagian dalam keduanya akan mengakibatkan perubahan pada bagian lain .

e. Bagian tersebut walaupun saling berkaitan dan merupakan struktur mikro tetapi dapat dipelajari secara terpisah.

Menurut Talcott Parson dalam Zamroni (1992, p.26) dengan teorinya The Structur of Social Action mengembangkan tentang konsep perilaku sukarela yang merupakan perilaku individu yang dapat dikembangkan ke dalam sistem sosial. Perilaku individu tersebut dikaitkan dengan situasi dalam hal ini berupa motive dan nilai. Tindakan mana yang akan diambil oleh individu ditentukan oleh jenis motive dan nilai yang mendominasi dalam diri seseotang. Konsep tersebut dapat disajikan pada Gambar 1.

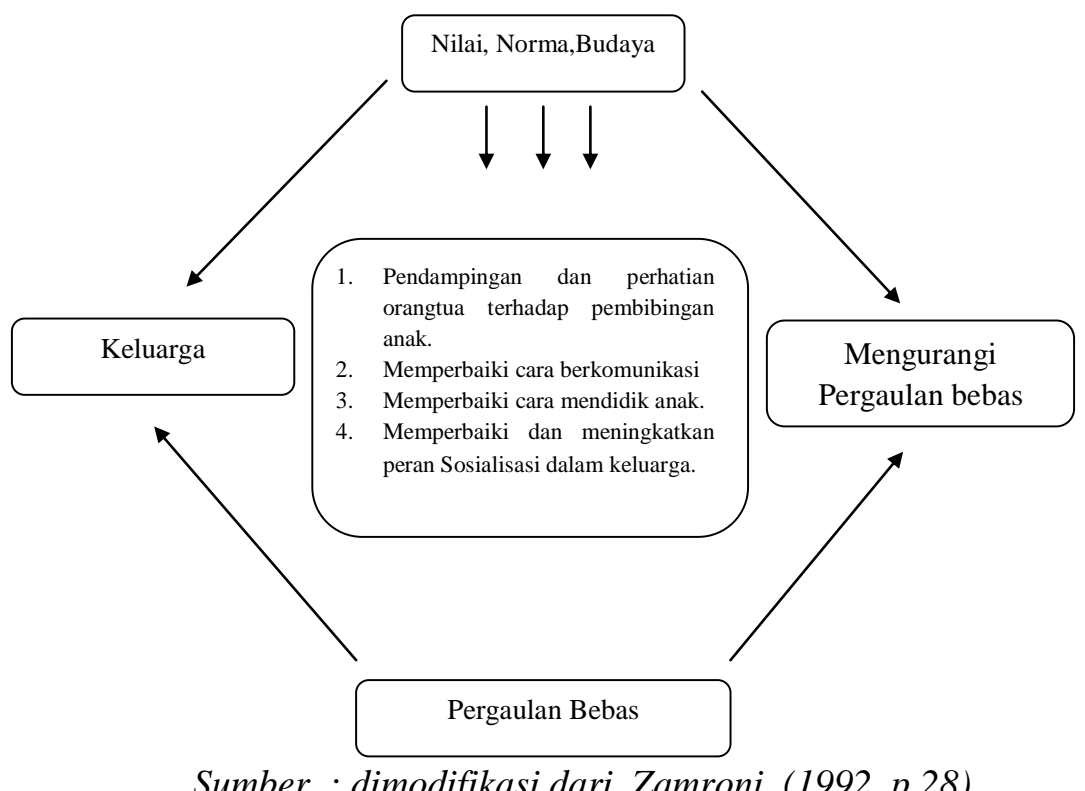

Sumber : dimodifikasi dari Zamroni, (1992, p.28)

Gambar 1. Struktur perilaku Talcott Parson

Kaitan dari teori ini terhadap pergaulan bebas remaja adalah bahwa remaja merupakan anggota dari suatu keluarga sehingga ketika di dalam keluarga tersebut para orang tua tidak melaksanakan fungsi dan peran mereka maka akan berdampak pada pembentukan kepribadian anak-anak mereka. Proses sosialisasi yang tidak sempurna yang dilakukan oleh orang tua akan mengakibatkan hal yang tidak baik dalam pembentukan kepribadian pada anak. Misalnya: pada lingkungan perokok jika sang anak tidak diawasi dan tidak diperdulikan oleh orang tua mereka maka me- 
mungkinkan anak tersebut untuk menjadi seorang perokok.

Kesulitan mengadakan hubungan yang serasi antara orang tua dan anak remaja pasti akan ada. Masalah yang menyebabkan kesulitan tersebut akan menyebabkan disorganisasi perilaku pada anak tersebut. Hubungan atau komunikasi yang tidak berjalan dengan baik itu akan menimbulkan suatu perilaku kenakalan yang dilakukan oleh anak mulai dari hal yang terkecil seperti membantah orang tua mereka karena mereka merasa tidak ada perhatian dari orang tua mereka.

Para remaja yang menentang orang tua pada dasarnya dapat dibedakan menjadi empat golongan yaitu:

1. Pemberontak yaitu remaja yang menentang/tidak mentaati semua pihak yang memegang kekuasaan sehingga mereka tidak mentaati semua kaidah dan norma yang berlaku. Pemberontakan ini biasanya dilakukan secara terbuka dan disertai amarah.

2. Pembaharu yaitu remaja yang berkeinginan untuk mengubah segala pola sikap tindak tradisional/adat istiadat karena menganggap hal tersebut penuh dengan kekurangan.

3. Aktivis yaitu golongan remaja yang sebenarnya merupakan pembaharu, akan tetapi mempergunakan cara yang lebih radikal/keras.

4. Golongan eksentrik merupakan golongan yang mengundurkan diri dari pergaulan umum dan menciptakan kaidah sendiri. Biasanya pertentangan ini dilakukan secara individual.

Pola pendidikan yang dilaksanakan oleh orang tua yang memegang peranan utama sehingga menghasilkan remaja yang patuh atau menentang terhadap orang tuanya tersebut. Pola pendidikan yang serba otoriter akan menciptakan keadaan remaja yang menjadi pemberontak karena orang tua mereka yang tergolong kalangan konservatif (kolot) yang tidak begitu memperhitungkan pembaharuan.

Keluarga merupakan institusi dasar yang memiliki peran yang besar dalam pembentukan karakter anak. Melalui proses pengasuhan serta pemberian teladan diharapkan akan berpengaruh pada perkembangan anak yang di dalamnya meliputi moral, loyalitas dan sosialisasi anak.

Untuk mencegah semakin maraknya pergaulan bebas di kalangan remaja dan untuk mewujudkan keluarga yang harmonis sangat diperlukan penanaman norma, nilai-nilai dan budaya. Sedangkan keluarga adalah tempat yang utama dimana seorang anak melakukan proses sosialisasi tentang norma dan nilai. Dalam keluarga pula seorang anak seharusnya merasa nyaman, merasa dilindungi dan dicintai. Untuk dapat membentuk keluarga yang harmonis maka sebuah keluarga harus mampu memberikan fungsi sosialisasi dan afeksi yang selama ini telah banyak dilupakan oleh sebagian besar keluarga modern. Untuk itulah diperlukan upaya-upaya yang dapat memperbaiki fungsi- fungsi yang ada dalam keluarga.

Saat ini untuk menekan jumlah pelaku pergaulan bebas terutama di kalangan remaja bukan hanya dengan membentengi diri mereka dengan unsur agama yang kuat. Selain itu juga perlu dibentengi dengan pendampingan orang tua dan selektif dalam memilih teman sebaya. Karena ada kecenderungan remaja lebih terbuka kepada teman sebayanya daripada dengan orang tua sendiri.

Upaya penanggulangan pergaulan bebas yang semakin marak terjadi di kalangan remaja saat ini memang mendesak untuk dilakukan. Berikut ini beberapa cara yang sekiranya dapat digunakan untuk menekan terjadinya pergaulan bebas antara lain:

1. Pendampingan dan perhatian orang tua terhadap pembimbingan anak

Sesibuk apapun orang tua dalam bekerja seyogyanya tetap menyisihkan waktu untuk anak-anaknya. Perhatian orang tua sangat diperlukan baik melalui pendampingan individu sampai pada mengenal kelompok atau teman bermain anaknya. Orang tua seyogyanya mengerti karakter anaknya, sehingga bisa memutuskan kapan untuk menarik dan kapan untuk melepas anak. Sehingga orang tua dapat senantiasa menjadi orang dekat bagi remaja. Melakukan komunikasi dengan anggota keluarga dan berbagi peran dalam membimbing anak. Karena pembagian peran dan tugas dalam keluarga terutama dalam pembimbingan anak sangat dibutuhkan untuk dapat 
saling melengkapi dan menjaga keharmonisan keluarga agar dapat berfungsi dengan baik. Oleh karena itu pembimbingan anak adalah tanggung jawab keluarga bukan hanya tanggung jawab seorang ibu.

2. Memperbaiki Cara Berkomunikasi

Memperbaiki cara berkomunikasi terutama dengan orang tua maupun dengan orang lain sehingga terbina hubungan baik. Karena keluarga yang kurang berkomunikasi dan berdialog akan menyebabkan rasa frustasi dan jengkel dalam jiwa anak-anak. Apabila orang tua tidak memberikan kesempatan dialog dan komunikasi dalam arti yang sesungguhnya, bukan hanya sekedar basa basi atau sekedar bicara pada hal-hal yang penting saja maka anak-anak tidak mungkin mau mempercayakan masalah-masalahnya dan membuka diri. Kenakalan remaja dapat disebabkan karena kurangnya dialog dalam masa kanak-kanak dan masa perkembangan. Karena orang tua terlalu menyibukkan diri sedangkan kebutuhan yang lebih mendasar yaitu cinta kasih diabaikan. Akibatnya anak menjadi terlantar dalam kesendirian dan kebisuan.

Selama ini komunikasi yang terjadi dalam keluarga kebanyakan masih dilakukan secara searah. Keluarga masih sedikit yang menerapkan komunikasi yang bersifat dialogis. Komunikasi dialogis dapat dilakukan dengan cara sederhana, misalnya dengan mengawali pembicaraan soal kegiatan di sekolah. Orang tua harus memiliki ketajaman analisa dan kemampuan berpikir yang luas dan integratif. Kepada anak hendaknya memiliki gaya bicara yang luwes dan bersahabat karena remaja tengah mencari jati dirinya.

Orang tua hendaknya membuka diri jika si anak bertanya atau mengajak diskusi tentang segala hal, termasuk halhal yang berbau seks. Dengan demikian anak tidak perlu berlebihan mencari eksistensi dan kasih sayang di luar rumah.

3. Memperbaiki Cara mendidik anak.

Keluarga mempunyai peran di dalam pertumbuhan dan perkembangan pribadi seorang anak. Karena keluarga merupakan lingkungan pertama dari tempat kehadirannya dan mempunyai fungsi untuk merawat dan mendidik anak. Dan cara bagaimana pendidikan itu diberikan akan menentukan seorang anak, karena pendidikan pada prinsipnya meletakkan dasar dan arah bagi seorang anak. Pendidikan yang baik akan mengembangkan kedewasaan pribadi anak, menjadi seorang yang mandiri, penuh tanggung jawab terhadap tugas dan kewajibanya, menghormati sesama manusia dan hidup sesuai martabat dan citranya. Sikap memanjakan anak pada dasarnya hanya akan meracuni anak itu sendiri. Karena anak menjadi tidak mandiri, dan akan lebih mudah putus asa apabila keinginannya tidak terpenuhi.

4. Memperbaiki dan meningkatkan peran Sosialisasi dalam keluarga.

Keluarga merupakan wadah dimana manusia mengalami proses sosialisasi awal, yakni suatu proses dimana manusia mempelajari dan mematuhi kaidah-kaidah dan nilai-nilai yang berlaku dalam masyarakat. Pola tingkah laku seorang anak tidak bisa terlepas dari pola tingkah laku orang tua dan lingkungan di sekitarnya. Oleh karena itu orang tua seharusnya memberikan teladan yang baik bagi anak-anaknya. Remaja harus bisa mendapatkan sebanyak mungkin figur orangorang dewasa yang telah melampaui masa remajanya dengan baik juga mereka yang berhasil memperbaiki diri setelah sebelumnya gagal pada tahap ini.

Anak-anak lain yang menjadi teman sepergaulannya sering kali mempengaruhi kepribadian seorang anak. Dari teman bergaul itu, anak akan menerima norma-norma atau nilai-nilai sosial yang ada dalam masyarakat. Dalam hal ini orang tua harus dapat mengarahkan pergaulan anak dengan menanamkan norma dan nilai yang berlaku di masyarakat, sehingga anak tidak larut terbawa ke dalam pergaulan yang tidak baik.

\section{SIMPULAN}

Pada dasarnya pergaulan bebas di kalangan remaja bukan merupakan hal yang baru lagi. Namun sampai saat ini masih banyak penelitian-penelitian yang menunjuk- 
kan bahwa perilaku menyimpang yang di lakukan remaja masih sangat tinggi bahkan dapat dikatakan mencapai titik yang mengkhawatirkan. Pergaulan bebas dapat terjadi pada dasarnya karena adanya sosialisasi yang tidak sempurna pada diri remaja. Remaja cenderung berusaha mencari jati dirinya pada teman sebayanya dan lingkungannya. Sehingga apabila salah dalam mencari teman dan bersosialisasi pada lingkungan yang salah mereka akan terjebak pada perilaku yang menyimpang.

Oleh karena itu peran dan fungsi orang tua sangat menentukan terhadap perilaku remaja pada saat ini. Kita tidak bisa menyalahkan modernisasi yang sedang berjalan, tapi kita sebagai orang tua perlu kebijakan dalam menyikapi modernisasi tersebut. Pada era modernisasi seperti ini keluarga terutama orang tua harus bisa membagi peran dan waktu untuk anak-anaknya. Untuk menekan pergaulan bebas di kalangan remaja tidak cukup hanya berupa penanaman nilai keagamaan yang kuat. Akan tetapi dibutuhkan pendampingan orang tua dalam segala hal, dengan tidak mengurangi kebebasan dari seorang anak. Fungsi sosialisasi dan afeksi dalam keluarga perlu ditumbuhkan kembali, mengingat keluarga adalah salah satu lembaga sosial yang paling dasar yang berperan membentuk karakter anak.

\section{DAFTAR PUSTAKA}

Anonim. (2011). Bahayanya pergaulan bebas di kalangan remaja. Diambil pada tanggal 23 Januari 2013 dari http://bekompas.blogspot.com/2011/10/ contoh-makalah-bahayanya pergaulan.html

Dwiningrum, S. I. A., (2012). Ilmu sosial \& budaya dasar: Pendekatan problem solving dan analisis kasus. Yogyakarta: UNY Press.

Eko A Meinarno,et al. (2011). Manusia dalam kebudayaa dan masyarakat: Pandang- an Antropologi dan Sosilogi. Jakarta: Salemba Humanika.

Faturochman. (2001). Revitalisasi peran keluarga. Buletin Psikologi, Tahun IX, No. 2, Desember 2001, 39-47, diambil pada tanggal 4 Februari 2013 dari http://fatur.staff.ugm.ac.id/file/JURNA L\%20\%20Revitalisasi\%20Keluarga.pdf

Goode, Willian J. (2007). Sosiologi keluarga. Jakarta: Bumi Aksara.

Henslin, James M. (2007). Sosiologi dengan pendekatan membumi. Jakarta: Erlangga.

Kartono, Kartini. (1992). Patologi sosial 2: kenakalan remaja. Jakarta: Rajawali.

Poloma, Margaret. (2007). Sosiologi Kontemporer. Jakarta: Raja Grafindo Persada

Rossi Yanne. Sex bebas di kalangan remaja. Diambil pada tanggal 19 Januari 2013 darihttp://kepri.bkkbn.go.id/Lists/ Artikel/DispForm.aspx?ID=130\&Conte ntTypeId=0x01003DCABABC04B708 4595DA364423DE7897.

Ritzer, George. (2003). Sosiologi ilmu pengetahuan berparadigma ganda. Jakarta: PT Raja Grafindo Persada.

Silalahi, Karlinawati \& Eko A Meinarno (Ed). (2010). Keluarga Indonesia: Aspek dan dinamika zaman. Jakarta: Raja Grafindo Persada.

Supardan, Dadang. (2011). Pengantar ilmu sosial: Sebuah kajian pendekatan struktural. Jakarta: Bumi Aksara.

Tiara Amelia. (2009). Pergaulan bebas di kalangan remaja. Diambil pada tanggal 19 Januari 2013 dari http://tiaraamelia. blogdetik.com/2009/11/03/pergaulan bebas/

Zamroni. (1992). Pengantar pengembangan teori sosial, Yogyakarta: Tiara Wacana. 